\title{
Thiamethoxam on the histological characteristics of sugarcane young roots
}

\author{
Tiametoxam nas características histológicas de raízes jovens de cana-de-açúcar
}

\author{
Raphael Gonçalves Martins ${ }^{\mathrm{I}}$ Maria Bernadete Gonçalves Martins' ${ }^{\mathrm{II}}$ João Marcelo Silva ${ }^{\mathrm{I}}$ \\ Marcelo Andrade Pereira ${ }^{I}$ Beatriz Appezzato-da-Glória' ${ }^{I}$ Paulo Roberto de Camargo e Castro ${ }^{{ }^{*}}$
}

\begin{abstract}
Thiamethoxam is a systemic insecticide from the neonicotinoid group, nitroguanidin family which affects the nicotinic receptor acetyl choline in the insect membrane, wounding the nervous system and causing the death of the insect. It was used with success in the control of initial pests of several crops. It was considered that thiamethoxam has a bioactivator effect, because in the absence of insects promoted increase in vigor, development and productivity of crops. This work was carried out to verify if thiamethoxam causes histological changes in sugarcane roots. In this work, it was used optical microscopy, images arrest, tissue biometrics and statistical analysis, in young roots of sugarcane RB 835486 after the treatments with different thiamethoxam concentrations. It was determined changes in histological structure of tissues 7 , 14, 21 and 28 days after the treatments, establishing its effects on root plant anatomy. It was verified that thiamethoxam increased root cortex width, increasing the vascular cylinder and the metaxylem vessel elements number in the vascular tissue until 21 days after application.
\end{abstract}

Key words: Saccharum spp., anatomy, root system.

\section{RESUMO}

O tiametoxam é um inseticida sistêmico do grupo neonicotinoide, da família nitroguanidina que atua no receptor nicotínico acetilcolina da membrana de insetos, lesando o sistema nervoso e levando-os à morte. Tem sido utilizado com sucesso no controle de pragas iniciais de diversas culturas. Considerou-se que o produto possui um efeito bioativador, uma vez que, mesmo na ausência dos insetos-praga, tem promovido aumento em vigor, desenvolvimento e produtividade de cultivos. No presente trabalho, foi analisada a anatomia de raízes jovens de cana-de-açúcar RB 835486 após aplicações de tiametoxam nas concentrações de 0,400 e $800 \mathrm{~g} \mathrm{ha}^{-1}$. As análises foram conduzidas aos 7, 14, 21 e 28 dias após as aplicações (DAA), no sentido de esclarecer seus efeitos na anatomia radicular da planta. Verificou-se que, até os 21DAA de desenvolvimento da cana-de-açúcar, thiametoxam amplia a espessura do córtex da raiz e aumenta o diâmetro do cilindro vascular, bem como o número de elementos de vaso do metaxilema, melhorando a absorção de água e sais minerais.

Palavras-chave: Saccharum spp., anatomia, sistema radicular.

\section{INTRODUCTION}

Brazil stands out as the world's largest sugarcane producer. It is one of the most important crops in the country and is spread over several parts of the Brazilian territory. Although its expansion is regarded as responsible for the reduction of world production of other foods, for environmental constraints in certain regions and competitiveness with fossil fuels, the Brazilian ethanol sees a promising future. The Companhia Nacional de Abastecimento (National Agency of Supply) - Conab - forecast the 2008/2009 Brazilian sugarcane crop to reach 8.9 million hectares, of which 7 million (roughly 558.6 million tons) should be allocated for sugar and ethanol production and other 151.6 million tons for other purposes such as seedling production, white rum and brown sugar (FNP CONSULTORIA\& \&OMÉRCIO, 2009).

Insecticides and fungicides are often studied as for their efficiency in controlling pests and diseases, respectively, nevertheless, they can cause physiological effects that affect crop development and, because they

\footnotetext{
'Departamento de Ciências Biológicas, Escola Superior de Agricultura "Luiz de Queiroz" (ESALQ), Universidade São Paulo (USP), 13418-900, Piracicaba, SP, Brasil. E-mail: prcastro@usp.br. *Autor para correspondência.

"Departamento de Biologia, Campus Experimental do Litoral Paulista, Universidade Estadual Paulista "Júlio de Mesquita Filho" (UNESP), São Vicente, SP, Brasil.
} 
are little known, they have not been properly assessed. Sugarcane growers have reported that after spraying their crops with thiamethoxam, one of the most widely used insecticide, plants had more vigor and development. It is interesting to establish if this product have some effect on histological characteristics of sugarcane roots. Chemicals are often used to attack field problems, however, research on morphological and physiological aspects of crops may reveal that they may enhance plant performance due to the management procedures applied.

Histological analysis of plant organs may show structural modifications responsible for changes in plant physiology and crop performance. Roots are affected by the most diverse plant hormones. The development of primary roots and their growth are subject to a synergistic and proportional action of auxin and cytokinin (MERCIER, 2004). Different management practices used in agriculture can alter the histological characteristics of plants (SILVA, 2005).

Thiamethoxam is used in Brazil for sugarcane cropping, recommended for the control of leafhopperroot (Mahanarva fimbriolata) at $1000 \mathrm{~g} \mathrm{ha}^{-1}$, and termites (Heterotermes tenuis) at $400 \mathrm{~g}$ to $800 \mathrm{~g} \mathrm{ha}^{-1}$, in water at 200 to $300 \mathrm{~L} \mathrm{ha}^{-1}$. It was considered that the thiamethoxam presents a bioactivator effect, increasing indirectly the synthesis of endogenous hormones (CASTRO \& PEREIRA, 2008), once even in the absence of insects, it promotes increase in vigor, development and productivity of the crop. Given the great importance of sugarcane culture and the use of one most widespread pesticide in this culture, assessing the effect of thiamethoxam can aggregate information for the crop development. Thus, the present study aimed to evaluate the effect of foliar sprays with thiamethoxam on the re-sprouting of sugarcane in terms of anatomical features of roots: root cortex, central cylinder diameter and number of elements of metaxylem vessels of the RB 835486 variety.

\section{MATERIALS AND METHODS}

The current research was carried out with sugarcane of the RB 835486 variety, in the Experimental Garden of the Department of Biological Sciences, ESALQ / USP between Sept 01 and Nov 09, 2009. To simulate ratoon, cutted clumps were planted in plastic pots filled with 20liters of substrate of clayey soil, originating from the B horizon, sand, vermiculite, limestone and fertilizers. Cutted clumps of $1.0 \mathrm{~kg}$ were used, which after five days of planting had the shoots pruned soon after they sprouted in order to standardize the new sprouting. The plants were irrigated to maintain the substrate close to the field capacity, and received fertilization with NPK (414-8), $3 \mathrm{~g}$ per vase. Three treatments were compared: control, $400 \mathrm{~g} \mathrm{ha}^{-1}$ and $800 \mathrm{~g} \mathrm{ha}^{-1}$ of the commercial product (c.p.) Actara ${ }^{\circledR} 250 \mathrm{WG}$ (thiamethoxam $250 \mathrm{~g} \mathrm{ha}^{-1}$ ) in foliar spray using water at $300 \mathrm{~L} \mathrm{ha}^{-1}$.

The treatments were applied 30 days after pruning, when plants had leaves about $50 \mathrm{~cm}$ high. The first evaluation was started after seven days of application and repeated every seven days, totaling four assessments, when the root system occupied the whole volume inside the vessel. Three replicates (subsamples) per treatment were used in each evaluation. The vessels were distributed in a randomized block design. Each plot consisted of a pot with a cutted clump.

Roots were separated from the soil with a jet of water and dried with paper towel. The assessment of root histological features was performed using transverse sections with 10 repetitions, $5 \mathrm{~cm}$ from root apex to transition region. Samples were fixed in FAA 70 (1:1:8 formaldehyde, glacial acetic acid and ethyl alcohol $70 \%$ ) for 24 hours, dehydrated in a graded ethanol series and embedded in hydroxyl-ethyl methacrylate (Leica Historesin). Serial sections were cut on a rotary microtome $(5 \mu \mathrm{m}$ thick), stained with $1 \%$ toluidine blue with $1 \%$ of sodium borate in $100 \mathrm{~mL}$ of distilled water (GERRITS, 1991).Photomicrographs were taken with a Leica $^{\circledR}$ DMLB photomicroscope equipped with a Leica ${ }^{\circledR}$ DC 300F camera.

Data of root histological analysis were subjected to variance analysis and, when significant, the means were compared using the Tukey test at $5 \%$ probability.

\section{RESULTS AND DISCUSSION}

Through the analysis of cross sections of young roots of sugarcane, it was possible to describe the effect of treatment with thiamethoxam at concentrations 400 g c.p. ha ${ }^{-1}$ and 800 g c.p. ha- ${ }^{-1}$ compared with plants of the control group, with analysis at $7,14,21$ and 28 days $\left(1^{\text {st }}, 2^{\text {nd }}, 3^{\text {rd }}\right.$ and $4^{\text {th }}$ weeks) after treatment. The roots were covered by the epidermis with few hairs in development.

The xylem was formed by conspicuous circle of about 10-12 elements of metaxylem vessels, and this number increases with the thickening and aging of the root. The root center was occupied by the spinal that is continuous and formed by round cells. The features observed confirm the descriptions of ARTSCHWAGER (1925) and VAN DILLEWIJN (1952).

Regarding the thickness of the root cortex (Table 1) significant interaction between collection time and thiamethoxam doses was observed. In the first week after the application of thiamethoxam, the dose of $800 \mathrm{~g} \mathrm{c.p.} \mathrm{ha} \mathrm{a}^{-1}$ caused a significant increase in the thickness of the root cortex, compared to other treatments. In the second week, the opposite was 
Table 1 - Thickness of root cortex $(\mu \mathrm{m})$ in sugarcane regarding thiamethoxam doses in foliar spraying and sampling time.

\begin{tabular}{lllll}
\hline Week & Control & $400 \mathrm{~g} \mathrm{ha}^{-1}$ & $800 \mathrm{~g} \mathrm{ha}^{-1}$ & Means \\
\hline 1 & $87.1 \mathrm{Bb}$ & $88.2 \mathrm{Bb}$ & $108.6 \mathrm{Ab}$ & 94.6 \\
2 & $92.0 \mathrm{Ab}$ & $87.5 \mathrm{Ab}$ & $79.0 \mathrm{Bc}$ & 86.2 \\
3 & $123.4 \mathrm{Ba}$ & $141.3 \mathrm{Aa}$ & $125.2 \mathrm{Ba}$ & 130.0 \\
4 & $60.7 \mathrm{Ac}$ & $56.0 \mathrm{Ac}$ & $60.7 \mathrm{Ad}$ & 59.1 \\
Means & 90.8 & 93.2 & 93.3 & $\mathrm{CV}=7.2 \%$ \\
\hline
\end{tabular}

Means followed by the same letter, uppercase in the line and lowercase in the column, do not differ significantly by Tukey test at $5 \%$ probability.

observed, i.e., the dose of $800 \mathrm{~g} \mathrm{ha}^{-1}$ reduced this parameter. In the third week, the dose of $400 \mathrm{~g}$ c.p. ha $^{-1}$ caused a significant increase in the cortex thickness as compared to the control and the dose of $800 \mathrm{~g} \mathrm{ha}^{-1}$. In the fourth week, the thiamethoxam doses showed no significant difference in the thickness of the root cortex. Study of roots structural aspects showed that roots developed in compacted soil tend to present higher cortex/thickness ratio of the vascular cylinder (QUEIROZ-VOLTAN et al., 1998).

The control treatment and the dose of $400 \mathrm{~g}$ c.p. ha ${ }^{-1}$ showed similar performance, maintaining the thickness of the root cortex constant from the first to the second week, increasing in the third week and decreasing in the fourth. While at a dose of $800 \mathrm{~g} \mathrm{c.p.} \mathrm{ha}{ }^{-1}$, the cortex thickness decreased from the first to the second week, it increased in the third week and decreased in the fourth. The diameter of the vascular cylinder showed a significant interaction between sampling times and doses of thiamethoxam applied (Table 2).

In the first week, the dose of $800 \mathrm{~g}$ c.p. $\mathrm{ha}^{-1}$ increased the diameter of the vascular cylinder as compared to the control treatment and the dose of $400 \mathrm{~g}$ c.p. ha ${ }^{-1}$. In the second week, there was no significant difference among the treatments. In the third week, the dose of $800 \mathrm{~g}$ c.p. ha $^{-1}$ caused a significant increase in the cylinder diameter while the dose of $400 \mathrm{~g}$ c.p. $\mathrm{ha}^{-1}$ reduced in comparison to the control. However, in the fourth week, the two doses of thiamethoxam reduced the diameter of the vascular cylinder as compared to control. Comparing the four sampling times within each treatment, the control treatment showed a gradual increase. The number of metaxylem vessel elements showed significant interaction between weeks of collection and dosages of thiamethoxam (Table 3 ).

In the first week after the application of thiamethoxam, the dose of $400 \mathrm{~g}$ c.p. $\mathrm{ha}^{-1}$ did not differ from control, while the dose $800 \mathrm{~g}$ c.p. ha $^{-1}$ significantly reduced the number of root metaxylem vessel elements. In the second week, the doses of 400 and $800 \mathrm{~g}$ c.p. ha $^{-1}$ thiamethoxam significantly increased the number of metaxylem vessel elements, with higher values for the higher dose. The same performance was observed in the third week. In the fourth week, the dosage of $400 \mathrm{~g} \mathrm{c.p.} \mathrm{ha}^{-1}$ increased the number of metaxylem vessel elements as compared to the dose of $800 \mathrm{~g} \mathrm{c.p.} \mathrm{ha}^{-1}$ and the control.

Between the sampling times, the control treatment significantly decreased the number of metaxylem vessel elements from the first to the second week and remained unchanged until the fourth week. The dose of $400 \mathrm{~g} \mathrm{c.p.}$ ha $^{-1}$ showed an increase from the first to the second week of evaluation, remaining equal in the third week and increased significantly in the fourth. The dose of $800 \mathrm{~g} \mathrm{c.p.}$ ha $^{-1}$ showed a significant increase from the first to the third week, decreasing slightly in the fourth.

Table 2 - Vascular cylinder diameter $(\mu \mathrm{m})$ of roots in sugarcane regarding doses of thiamethoxam in foliar spraying and sampling time.

\begin{tabular}{lllll}
\hline Week & Control & $400 \mathrm{~g} \mathrm{ha}^{-1}$ & $800 \mathrm{~g} \mathrm{ha}^{-1}$ & Means \\
\hline 1 & $79.2 \mathrm{Bb}$ & $86.9 \mathrm{Ba}$ & $113.2 \mathrm{Ab}$ & 93.1 \\
2 & $102.1 \mathrm{Ab}$ & $97.2 \mathrm{Aa}$ & $98.5 \mathrm{Ac}$ & 99.3 \\
3 & $124.4 \mathrm{Ba}$ & $92.7 \mathrm{Ca}$ & $136.4 \mathrm{Aa}$ & 117.8 \\
4 & $124.8 \mathrm{Aa}$ & $60.2 \mathrm{Bb}$ & $62.0 \mathrm{Bd}$ & 82.3 \\
Means & 107.6 & 84.2 & 102.5 & $\mathrm{CV}=10.1 \%$ \\
\hline
\end{tabular}

Means followed by the same letter, uppercase in the line and lowercase in the column, do not differ significantly by Tukey test at $5 \%$ probability. 
Table 3 - Number of metaxylem vessel elements of roots in sugarcane regarding doses of thiamethoxam in foliar spraying and sampling time.

\begin{tabular}{lllll}
\hline Week & Control & $400 \mathrm{~g} \mathrm{ha}^{-1}$ & $800 \mathrm{~g} \mathrm{ha}^{-1}$ & Means \\
\hline 1 & $10.0 \mathrm{Aa}$ & $10.0 \mathrm{Ac}$ & $9.2 \mathrm{Bd}$ & 9.7 \\
2 & $9.0 \mathrm{Cb}$ & $11.2 \mathrm{Bb}$ & $12.0, \mathrm{Ab}$ & 10.7 \\
3 & $9.0 \mathrm{Cb}$ & $10.6 \mathrm{Bbc}$ & $15.2 \mathrm{Aa}$ & 11.6 \\
4 & $9.2 \mathrm{Cb}$ & $12.9 \mathrm{Aa}$ & $11.2 \mathrm{Bd}$ & 11.1 \\
Means & 9.3 & 11.2 & 11.9 & $\mathrm{CV}=5.3 \%$ \\
\hline
\end{tabular}

Means followed by the same letter, uppercase in the line and lowercase in the column, do not differ significantly by Tukey test at $5 \%$ probability.

The number of metaxylem vessel elements represents the capacity of the plant to absorb water and nutrients, and the increase of the number of metaxylem vessel elements is beneficial for the plant to augment absorption efficiency. PASSIOURA (1972) found that breeding for narrower xylem vessels in the seminal roots of wheat can increase the hydraulic resistance and make plants use ground water more slowly during the growing season, increasing its availability for grain filling and production in periods of dry weather.

These results corroborate the hypothesis of CASTRO \& PEREIRA (2008) that the application of thiamethoxam in plants activates transcription and repression/expression of certain genes, promoting the action of metabolic enzymes and membrane proteins that favor the absorption of water and nutrients, leading to increases in productivity.
These data allow to observe that in the initial phase of root growth, the application of thiamethoxam showed greater development of cortex cells. Young plants with thicker cortical parenchyma may show better fixation in the soil taking more vigor. Thiamethoxam provided greater growth of vascular cylinder in the first weeks, which may favor the establishment of plants, and also increased the number of elements of metaxylem vessel, which favors the absorption of water and nutrients.

The initial phase of root development of sugarcane confirms the data obtained and that for the

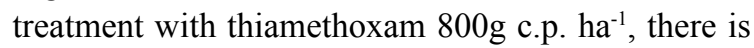
expansion of the cortical tissue, increasing the diameter of the vascular cylinder and the number of elements of metaxylem vessel (Figure 1).

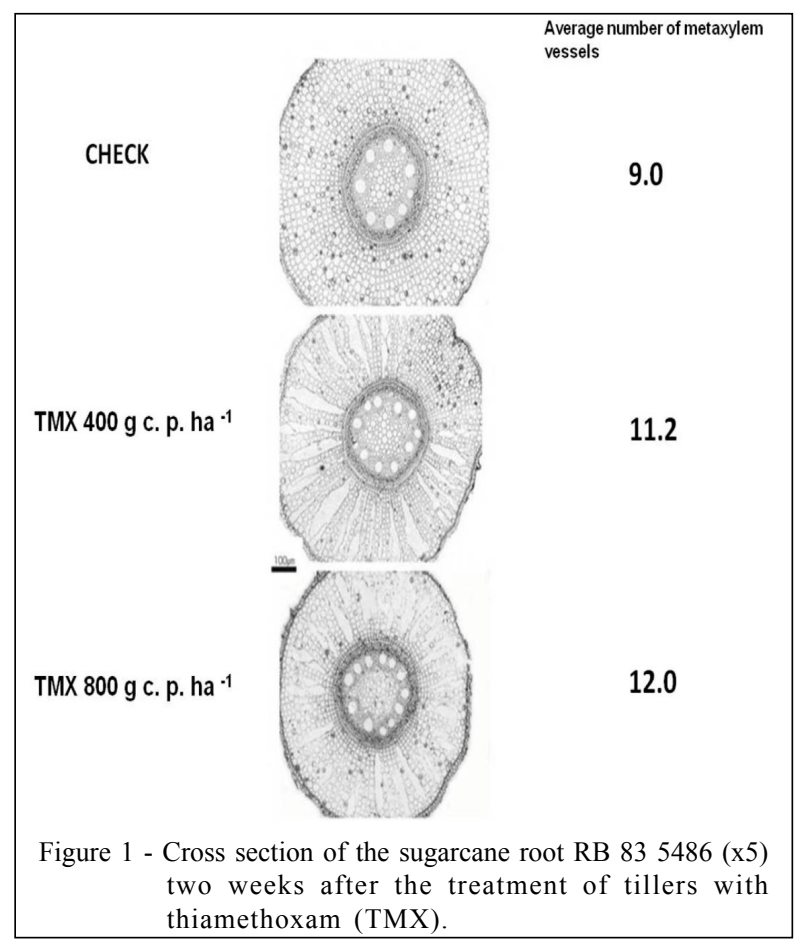

Ciência Rural, v.42, n.11, nov, 2012. 
These anatomical changes increase the efficiency of the root system to fix and absorb nutrients. RAVNIKAR et al. (1992) also observed similar effects in the application of jasmonic acid in potato, and that BAUSHER \& YELENOSKY (1986) and BARNES et al. (1989) reported restrictions in root development of citrus, soybeans and corn treated with triazoles.

Figure 1 shows that in the second week of root sampling, in the treatment with a dose of $800 \mathrm{~g}$ c.p. $\mathrm{ha}^{-1}$, thiamethoxam reduced the cortex thickness, the bioactivator did not alter the vascular cylinder as compared to control, but the number of elements of metaxylem vessel in the two treatments with thiamethoxam was higher than that in the control. This result is important because modifications of the number of elements of xylem vessel could change the geometry of the root system and it capacity of absorption of water and mineral salts.

\section{CONCLUSION}

The application of thiamethoxam as foliar spray in sugarcane cuttings RB 835486 increases the diameter of the vascular cylinder and the number of elements of metaxylem vessels in adventitious roots in the first weeks after spraying.

\section{REFERENCES}

ARTSCHWAGER, E. Anatomy of the vegetative organs of sugar cane. Journal of Agricultural Research, v.30, n.3, p.197-221, 1925.

BARNES, AM. et al. Anatomy of Zea mays and Glycine max seedlings treated with triazole plant growth regulator. Biologia Plantarum, v.31, n.5, p.370-375, 1989.
BAUSHER, M.G; YELENOSKY, G. Sensitivity of potted citrus plants to top sprays and soil applications of paclobutrazol. HortScience, v.21, n.1, p.141-143, 1986.

CASTRO, P.R.C.; PEREIRA, M.A. Bioativadores na agricultura. In: GAZZONI, D.L. Tiametoxam: uma revolução na agricultura brasileira. São Paulo: Vozes, 2008. p.118-125.

FNP CONSULTORIA \& COMÉRCIO. Mercados \& Perspectivas. In: AGRIANUAL 2009. Anuário da agricultura brasileira. São Paulo: Instituto FNP, 2009. p.235-250.

GERRITS, P.O. The application of glycol metacrylate in histotechnology: some fundamental principles. Gröningen: Department of Anatomy and Embriology, 1991. 239p.

MERCIER, H. Auxinas. In: KERBAUY, G.B. (Ed.). Fisiologia vegetal. Rio de Janeiro: Guanabara Koogan, 2004. p.217-249.

PASSIOURA, J.B. The effect of root geometry on the yield of wheat growing on stored water. Australian Journal of Agricultural Research, v.25, p.745-752, 1972.

QUEIROZ-VOLTAN, R.B. et al. Aspectos estruturais do cafeeiro infectado com Xylella fastidiosa. Bragantia, v.58, n.1, p.23-33, 1998. Disponível em: <http://www.scielo.br/ s c i e 1 o.php? s c i p t $=$ s c i a b s tract \& pi d = S 0006 $87051998000100003 \& \operatorname{lng}=\mathrm{en} \& \mathrm{nrm}=\mathrm{iso} \& \mathrm{t} \operatorname{lng}=\mathrm{pt}>$. Acesso em: 14 ago. 2010. doi: 10.1590/S0006-87051998000100003.

RAVNIKAR, M. et al. Stimulatory effects of jasmonic acid on potato stem node and protoplast culture. Journal Plant Growth Regulation, v.11, p.29-33, 1992.

SILVA, L.M. et al. Inter-relações entre a anatomia vegetal e a produção vegetal. Acta Botanica Brasilica, v.19, n.1, p.183194, 2005. Disponível em: <http://www.scielo.br/ scielo.php?script=sci_art text \& pid = S $0102-$ $33062005000100018 \& \operatorname{lng}=\mathrm{pt} \& \mathrm{nrm}=\mathrm{iso} \& \mathrm{t} \operatorname{lng}=\mathrm{pt}>$. Acesso em: 15 maio, 2010. doi: 10.1590/S0102-33062005000100018.

VAN DILLEWIJN, C. Botany of sugarcane. Chronica Botanica, v.1, p.53-58, 1952. 